\title{
Dlaczego Bóg uczynił Chrystusa grzechem (2 Kor 5, 21)?
}

W 2 Kor 5, 21 znajduje się zaskakujące wyrażenie: „Tego, który nie znał

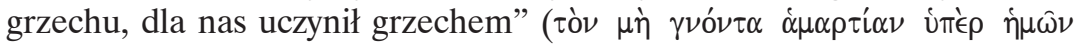

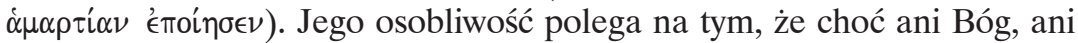
Chrystus nie są wymienieni tutaj „imiennie”, kontekst wersetu 21 wyraźnie wskazuje, iż podmiotem działającym jest tutaj Bóg Ojciec, odbiorcą zaś Jego działania jest Chrystus. Paweł twierdzi więc, że Ojciec uczynił Chrystusa grzechem $^{1}$. Nigdzie indziej w Nowym Testamencie nie znajdujemy takiego lub podobnego stwierdzenia. Artykuł ten jest najpierw próbą znalezienia odpowiedzi na pytanie: Co to znaczy, że Chrystus został uczyniony grzechem? $\mathrm{Na}$ drugim zaś etapie naszych poszukiwań zajmiemy się problematyką skutków uczynienia Chrystusa grzechem, które są wyrażone przez Pawła w 2 Kor 5, 21b za pomocą stwierdzenia „abyśmy się stali sprawiedliwością

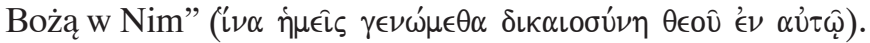

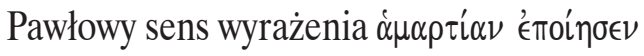

$\mathrm{W}$ pełnym brzmieniu werset 5,21 przedstawia się następująco:

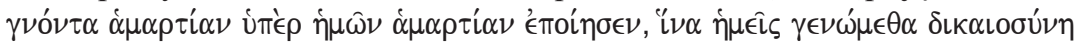

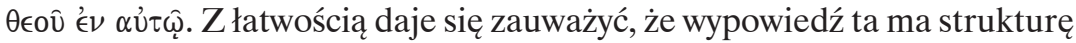
koncentryczną ${ }^{2}$ :

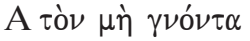

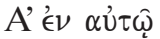
$\mathrm{B} \dot{\alpha} \mu \alpha \rho \tau i \alpha \nu$

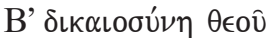
C u̇Tí̄ $\dot{\eta} \mu \omega \hat{\omega} \nu$
C'

$\mathrm{D} \dot{\alpha} \mu \alpha \rho \tau \dot{\imath} \alpha \nu \dot{\epsilon}^{\prime} \pi o^{\prime} \eta \sigma \epsilon \nu$

${ }^{1}$ To Pawłowe stwierdzenie przyciągało już wielokrotnie uwagę egzegetów. Najwięcej miejsca poświęcili mu: W. H. GloER, An Exegetical and Theological Study of Paul's Understanding of New Creation and Reconciliation in 2 Cor. 5: 14-21, Macon 1996 (zwłaszcza s. 95-107); L. SABOURIN, Note sur 2 Cor. 5, 21. Le Christ fait 'peché', „Sciences Ecclésiastiques” 11 (1959), s. 419-424; S. LYONNET, L. SAbourin, Sin, Redemption and Sacrifice. A Biblical and Patristic Study, Rome 1970, s. 185-289; R. Bieringer, J. Lambrecht, Studies on 2 Corinthians, Leuven 1994, s. 473-495.

${ }^{2}$ Por. M. J. Harris, The Second Epistle to the Corinthians. A Commentary on the Greek Text, Grand Rapids 2005, s. 449. 


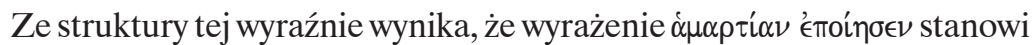
centralny element wersetu 21, na którym spoczywa emfaza całej wypowiedzi. Należy zwrócić uwagę na to, że na początku wersetu 21 brakuje partykuły łączącej treść tego zdania z kontekstem uprzednim. Wskazuje to na intencję Pawła, by skierować uwagę czytelnika na samo znaczenie tej wypowiedzi i nadać jej emfatyczny charakter. Wersetu 21 nie należy jednakże izolować od jego kontekstu uprzedniego i następnego, bez których zdanie to staje się bardzo enigmatyczne. Wersety 14 i 15 piątego rozdziału przygotowują tło dla wypowiedzi o uczynieniu Chrystusa grzechem. Trzykrotnie Paweł powtarza w nich prawdę o tym, że „Chrystus umarł za wszystkich” (w 14a

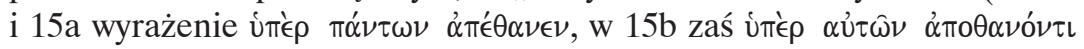

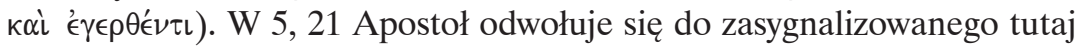
motywu śmierci Chrystusa za wszystkich i wyjaśnia, w jaki sposób wierzący mają udział w tym zbawczym wydarzeniu (ư⿰亻卬 $\dot{\eta} \mu \hat{\omega} \nu$ ). W wersecie $18 \mathrm{~Pa}$ weł wyjaśniał Koryntianom, że obecny stan zbawienia ma swoje źródło „w Bogu”, który „przez Chrystusa” pojednał ich ze sobą. Myśl ta jest podjęta i doprecyzowana w wersecie 21, gdzie Apostoł pisze, że stało się to dzięki

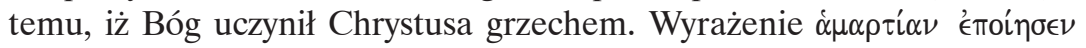
z wersetu 21 jest również podsumowaniem tego, co Paweł napisał w wersecie 19: Bóg „nie liczy” ludziom ich grzechów dzięki temu, że w Chrystusie „pojednuje” świat ze sobą. Grzechy ludzkie zostały więc złożone na Chrystusa, którego Bóg uczynił grzechem. Kulminacją Pawłowej argumentacji o zbawczych skutkach śmierci Jezusa rozwijanej w 5, 14-19 jest jego ekskla-

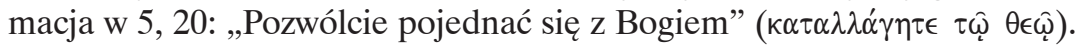
Tak więc werset 21 ma charakter emfatyczny i podsumowujący Pawłową argumentację na temat sposobu pojednania człowieka z Bogiem. Pojednanie to dokonało się przez śmierć Jezusa, dzięki temu, że Bóg uczynił Go grzechem. W kontekście następującym po wierszu 21 prawdy o zbawczych owocach śmierci Chrystusa można się dopatrzeć w 6, 2 w wyrażeniach: ' $e v$

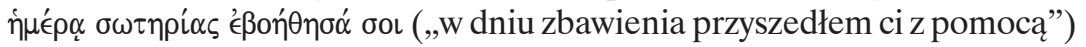

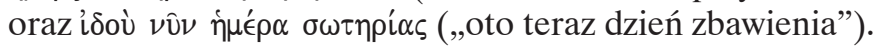

W wersecie 21 Paweł określa Chrystusa jako „Tego, który nie znał grzechu" (

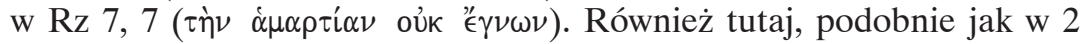
Kor 5, 21, rzeczownik $\dot{\alpha} \mu \alpha \rho \tau i \alpha$ stanowi dopełnienie bliższe czasownika $\gamma \iota \nu \omega ́ \sigma \kappa \omega$. Różnica polega jednak na tym, że w Rz 7, 7 podmiotem nieznajomości grzechu jest sam Paweł, który argumentuje, że bez Prawa nie byłby zdolny rozpoznać grzechu³. Jak więc należy rozumieć stwierdzenie

${ }^{3}$ Szerzej na temat Pawłowego rozumienia grzechu w Rz 7, 7 zob. B. Byrne, Romans, Collegeville 1996, s. 219. 
o nieznajomości grzechu w 2 Kor 5, 21? Dla określenia nieznajomości

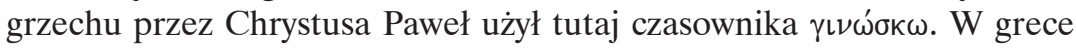
klasycznej kompetencje semantyczne tego czasownika były ściśle określone. Używano go mianowicie na określenie dochodzenia do poznania jakiejś rzeczywistości w odróżnieniu od czasownika oî̉ $\alpha$, który stosowano mówiąc o posiadanej już wiedzy ${ }^{4}$. Konsekwentnie $\gamma\llcorner\nu \omega ́ \sigma \kappa \omega$ oznaczało zdobywanie wiedzy przez uczenie się, obserwację i osobiste doświadczenie ${ }^{5}$. Oî́ $\alpha$ zaś to poznanie poprzez intuicyjny wgląd w jakąś rzeczywistość. Takie znaczenie tych czasowników zdaje się utrzymywać jeszcze greka hellenistyczna ${ }^{6}$. Widać to również u Pawła, choćby w 2 Kor 5, 16, w perykopie, do której strukturalnie przynależy werset 21: „Tak więc i my odtąd już nikogo nie

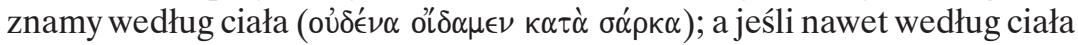

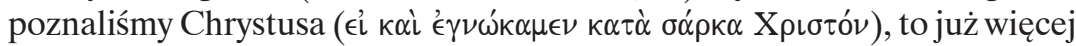

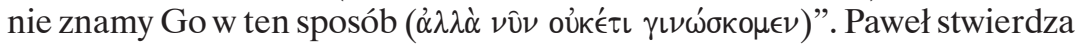
więc w wersecie 21, że Jezus nie miał osobistego doświadczenia grzechu. Imiesłów $\gamma \nu o ́ v \tau \alpha$ został tutaj poprzedzony rodzajnikiem tó $\nu$, dzięki czemu przyjmuje formę rzeczownikową, co nadaje mu walor pozaczasowy i każe wnioskować o bezgrzeszności Chrystusa nie tylko podczas Jego ziemskiego życia, lecz także przed wcieleniem? ${ }^{7}$. Wskazywać może na to również obecna tutaj partykuła przecząca $\mu \eta ́$, która w opinii wielu egzegetów przyjmuje w tym wyrażeniu wartość emfatyczną̨: Apostoł stwierdza więc, że Chrystus „nigdy nie znał grzechu w jakichkolwiek jego przejawach”. Pawłowe przeświadczenie o bezgrzeszności Chrystusa przed wcieleniem jest wyrażone w sposób niebezpośredni również w Rz 5, 19 i Flp 2, 8, gdzie Apostoł mówi o doskonałym wypełnieniu przez Niego woli Ojca. Przekonanie

${ }^{4}$ Zob. H. SeEsemann, Oîj $\alpha$, [w:] Theological Dictionary of the New Testament, eds. G. Kittel and G. Friedrich, transl. by G.W. Bromiley, Grand Rapids 1981 [Electronic Edition 2000], 5.116.

${ }^{5}$ Czasownik $\gamma \iota \nu \omega ́ \sigma \kappa \omega$ należy tutaj widzieć jako odpowiednik hebrajskiego jd'.

${ }^{6}$ Użycie tych czasowników w Corpus Paulinum przeanalizował D. W. Burdick, który stwierdził, że na 153 wystąpienia obu czasowników u Pawła, w 18 przypadkach są one stosowane zamiennie, w pozostałych zaś zachowują swoje klasyczne rozróżnienie; por. D. W. Burdick,

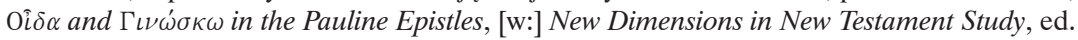
by R. N. Longenecker, M. C. Tenney, Grand Rapids 1974, s. 344-356. Rozróżnienie kompetencji semantycznych tych dwóch czasowników w Nowym Testamencie proponują również: J. P. Louw, E. A. NIDA, Greek-English Lexicon of the New Testament Based on Semantic Domains, t. 1-2, New York 1988 [Electronic Edition 2003], BibleWorks 6, 1367. 4527.

${ }^{7}$ M. J. HARris, The Second Epistle to the Corinthians..., dz. cyt., s. 450, uważa, że Paweł akcentuje tutaj raczej wolność Chrystusa od grzechu podczas jego ziemskiego życia. Nato-

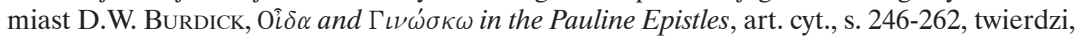
że Paweł ma tutaj na myśli tylko czas przed wcieleniem.

${ }^{8}$ Dyskusję na ten temat zob. w: M. J. Harris, The Second Epistle to the Corinthians..., dz. cyt., s. 450, przypis 173 . 
o bezgrzeszności Jezusa jest również poświadczone przez innych autorów Nowego Testamentu (np. J 8, 46; Dz 3, 14; Hbr 7, 26; 1 P 2, 22; 1 J 3, 5).

Dochodzimy więc do sedna problemu postawionego w tym artykule: co oznacza Pawłowe stwierdzenie, że Bóg uczynił Chrystusa grzechem

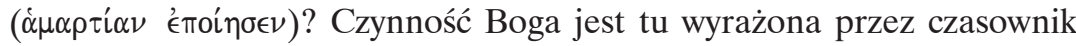

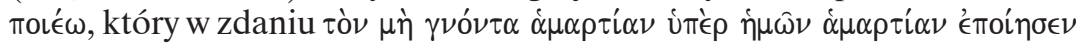

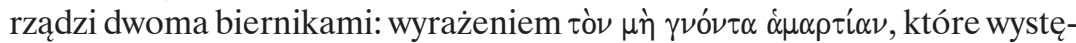
puje w funkcji dopełnienia bliższego oraz $\alpha \mu \alpha \rho \tau$ tí $\alpha$, które przyjmuje tu rolę orzecznika. W historii egzegezy zdanie to było interpretowane w dwojaki sposób. Jeżeli przyjmiemy tutaj podstawowe znaczenie czasownika noเ́́ $\omega$ („przemienić coś w coś innego” albo „uczynić kogoś czymś”), wówczas wypowiedź Pawła należy przetłumaczyć literalnie: „Tego, który nie znał

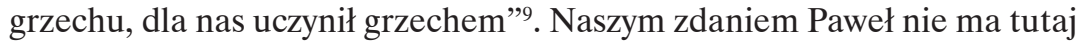
na myśli przemiany Jezusa w kogoś innego, lecz chce ukazać sprawczą przyczynowość Boga ${ }^{10} \mathrm{~W}$ uczynieniu Jezusa „narzędziem” pojednania ludzkości ze sobą. H. G. Liddell i R. Scott, analizując użycie czasownika moléw u starożytnych autorów greckich, wskazują, że w takim właśnie sprawczym znaczeniu stosowali go na przykład Herodot, Tukidydes czy Ksenofont ${ }^{11}$. J. P. Louw i E. A. Nida pośród licznych semantycznych kompetencji czasownika noเ́́ $\omega$ w Nowym Testamencie widzą również odcień kauzatywny o znaczeniu zbliżonym do takich czasowników, jak $\tau^{i} \theta \eta \mu$,

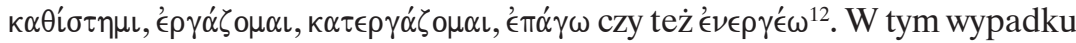
fragment ten należałoby przetłumaczyć: „,Bóg] sprawił (zdecydował), że Ten, który nie znał grzechu, stał się grzechem”. Taka interpretacja doskonale koresponduje z kontekstem uprzednim tej wypowiedzi, gdzie Paweł wyjaśnia, że „Bóg jednał świat ze sobą w Chrystusie, nie poczytując ludziom ich grzechów” $(5,19)$. Bóg więc sprawił, że Chrystus stał się grzechem, po to, by ludzi uwolnić od grzechu. Dla określenia beneficjentów Bożego działania Paweł używa w 5, 21 wyrażenia ưṫ̇ $\dot{\eta} \mu \omega \hat{\nu}$. Kontekst uprzednich wersetów, zwłaszcza 14 i 15, gdzie jest mowa o tym, że Chrystus umarł

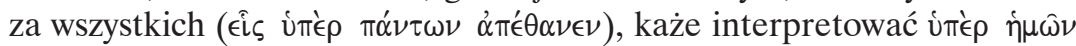
w 5, 21 jako odnoszące się do całej ludzkości, a nie tylko do Pawła, jego

${ }^{9}$ Taką interpretację przyjmuje na przykład J. D. G. Dunn, The Theology of Paul the Apostle, Grand Rapids 1998, s. 222.

${ }^{10}$ Za kauzatywną interpretacją czasownika noเ́́ $\omega$ w tym zdaniu opowiada się np. M. J. Harris, The Second Epistle to the Corinthians..., dz. cyt., s. 451.

${ }^{11}$ Zob. H. G. Liddell, R. ScotT, A Greek-English Lexicon, revised by H. S. Jones, Oxford 1968 (Electronic Edition 2003), 32940.

${ }^{12}$ Zob. J. P. Louw, E. A. NIDA, Greek-English Lexicon of the New Testament Based on Semantic Domains, dz. cyt., 13.9. 
ewentualnych współpracowników i Koryntian. Paweł wyraża tutaj prawdę uniwersalną, a cały werset 21 ma charakter gnomiczny.

Kolejne pytanie, jakie się tutaj rodzi, dotyczy momentu, w którym zdaniem Pawła Bóg sprawił, że Chrystus stał się grzechem dla ludzkości. Część komentatorów odnosi tę wypowiedź apostoła do wcielenia Syna Bożego oraz całego Jego ziemskiego życia. Inni natomiast uważają, że chodzi tutaj o krzyżową śmierć Jezusa ${ }^{13}$. W pierwszym przypadku chodziłoby o wyeksponowanie przez Pawła momentu wcielenia Chrystusa jako chwili, gdy przyjął On ludzką naturę wraz ze wszystkimi konsekwencjami - także grzechu i śmierci ${ }^{14}$. Koncepcja ta nie znajduje jednakże paraleli w innych pismach Pawłowych, gdyż Apostoł nie mówi nigdzie o przyjęciu przez Jezusa „grzesznego ciała”, a wręcz unika takiego stawiania sprawy. Widać to wyraźnie w Rz 8, 3, gdzie Paweł jasno stwierdza, że Jezus przyjął ciało

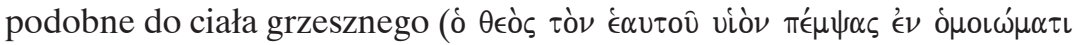

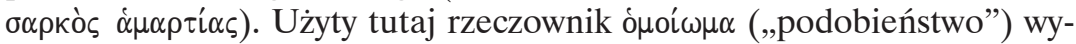
raźnie wskazuje, że Paweł chciał uzmysłowić chrześcijanom w Rzymie, iż ziemski Jezus nie posiadał grzesznej natury, lecz naturę podobną do „grzesznego ciała”. „Uczestnictwo w ludzkiej naturze nie było grzechem, ani nie uczyniło z Niego [Jezusa] grzesznika"15.

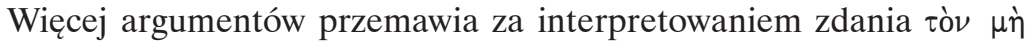

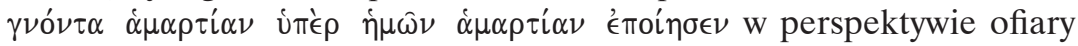
krzyżowej Jezusa. Tematyka śmierci Jezusa, na co już zwróciliśmy uwagę, pojawiła się już trzykrotnie w kontekście uprzednim, w wersetach 14-15: „Albowiem miłość Chrystusa przynagla nas, pomnych na to, że skoro Jeden umarł za wszystkich, to wszyscy pomarli. A właśnie za wszystkich umarł Chrystus po to, aby ci, co żyją, już nie żyli dla siebie, lecz dla Tego, który za nich umarł i zmartwychwstał". W sposób zawoalowany wybrzmiewa ona również w wersecie 18: „Wszystko zaś to pochodzi od Boga, który pojednał nas z sobą przez Chrystusa i zlecił nam posługe jednania”. Werset 21 wydaje się więc być naturalną kontynuacją i konkluzją tych wypowiedzi. Paweł interpretuje tutaj śmierć Chrystusa na krzyżu jako „ofiarę za grzechy świata" ${ }^{16}$. Należy zwrócić uwagę na zabieg retoryczny Pawła polegający na dwukrotnym użyciu w 5, 21 tego samego rzeczownika $\dot{\alpha} \mu \alpha \rho \tau i \alpha$. W pierwszym

${ }^{13}$ Zob. dyskusję na ten temat w: M. J. HARris, The Second Epistle to the Corinthians..., dz. cyt., s. 451.

${ }^{14}$ Za tą interpretacją opowiadają się na przykład: D. E. H. Whiteley, The Theology of St. Paul, Philadelphia 1964, s. 137; E. KäsEmann, Perspectives on Paul, Philadelphia 1971, s. 43.

${ }^{15}$ M. J. Harris, The Second Epistle to the Corinthians..., dz. cyt., s. 452.

${ }^{16}$ Taką interpretację przyjmują na przykład: S. LyOnnEt, L. SABOuRIn, Sin, Redemption and Sacrifice..., dz. cyt., s. 251nn; C. H. TALBERT, Reading Corinthians. A Literary and Theological Commentary on 1 and 2 Corinthians, New York 1987, s. 167n. 
wystąpieniu, które analizowaliśmy powyżej, rzeczownik ten jest użyty w swoim podstawowym znaczeniu określającym przewinienie popełnione wobec Boga poprzez sprzeciwienie się Jego woli ${ }^{17}$. Istnieje natomiast wśród egzegetów rozbieżność opinii, jeśli chodzi o zamierzony przez Pawła sens

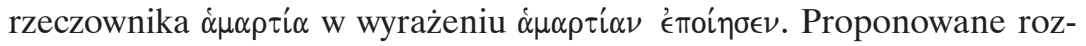
wiązania można sprowadzić do czterech punktów ${ }^{18}$ :

\section{CHRYSTUS JAKO GRZECH}

Poszczególni komentatorzy wydobywają różne odcienie wyrażenia

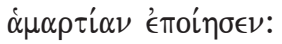

- Chrystus został potraktowany przez Boga tak, jakby był ucieleśnieniem grzechu ${ }^{19}$;

- Bóg sprawił, że Chrystus rzeczywiście stał się grzechem, jego personifikacją wraz z wszystkimi konsekwencjami ${ }^{20}$;

- Chrystus stał się grzechem wobec Boga dlatego, że „stanął wobec Niego w relacji, która normalnie jest rezultatem grzechu, został oddalony od Boga i stał się przedmiotem Jego gniewu"21.

CHRYSTUS JAKO TEN, KTÓRY WZIĄ NA SIEBIE GRZECHY

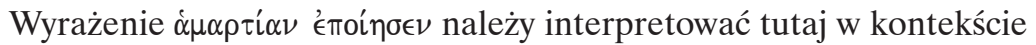
w. 19, gdzie zostało powiedziane, że „w Chrystusie Bóg jednał ze sobą świat, nie poczytując ludziom ich grzechów”. Paweł zdaje się uświadamiać tutaj Koryntianom, że grzechy ludzkości zostały przez Boga przeniesione na bezgrzesznego Chrystusa. Bóg więc pojednał świat ze sobą przez to, że Jezus wziął na siebie grzechy ludzkości i stał się personifikacją grzechu.

${ }^{17}$ U greckich pisarzy począwszy od Ajschylosa i Tukidydesa rzeczownik ten w swoim podstawowym znaczeniu określa „błąd polegający na niezrozumieniu czegoś,, „chybienie celu”, ,zły czyn”; por. więcej na ten temat: J. H. THAYER, A Greek-English Lexicon of the New Testament, BibleWorks 7, 227.

${ }^{18}$ Poglądy te referuję za: M. J. Harris, The Second Epistle to the Corinthians..., dz. cyt., s. $452-454$.

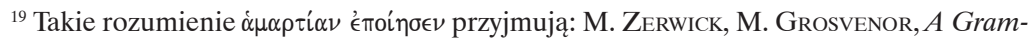
matical Analysis of the Greek New Testament, 5 ed., Rome 1996, s. 545: "God treated him as if he had been sin's embodiment".

${ }^{20}$ Zob. A. T. Robertson, Second Corinthians, [w:] tenże, Word Pictures in the New Testament IV. The Epistles of Paul, Nashville 1931, s. 233; R. BIERINGER, Sünde und Gerechtigkeit Gottes in 2 Korinther 5, 21, [w:] R. Bieringer, J. Lambrecht, Studies on 2 Corinthians, dz. cyt., s. 508.

${ }^{21}$ C. K. Barrett, A Commentary on the Second Epistle to the Corinthians, New York 1973, s. 180. 
Dokonało się to w momencie krzyżowej śmierci Jezusa, który przyją ją w zastępstwie każdego grzesznika, popełniającego jakikolwiek grzech ${ }^{22}$.

\section{Chrystus JAKO GRZESZNIK ${ }^{23}$}

Bóg potraktował bezgrzesznego Chrystusa tak, jakby był grzesznikiem, jako grzesznika. Abstrakcyjny rzeczownik $\dot{\alpha} \mu \alpha \rho \tau$ t $\alpha$ przyjmuje tutaj konkretne znaczenie „grzesznik” i określa stan Chrystusa, który został uczyniony

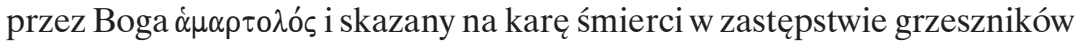
(odniesienie do w. 19).

\section{CHRYSTUS JAKO OFIARA ZA GRZECHY}

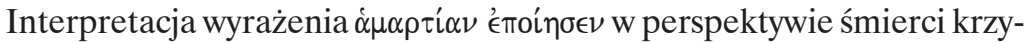
żowej Chrystusa nieodparcie narzuca skojarzenie tego wydarzenia z kultem ofiarniczym Starego Testamentu. Skojarzenie to nabiera szczególnego waloru w perspektywie znajomości semantyki występowania rzeczownika $\dot{\alpha} \mu \alpha \rho \tau i \alpha$ w Septuagincie. Otóż w Biblii Hebrajskiej dwa podstawowe terminy występujące na określenie grzechu: hatțā't i 'āšām są używane również w znaczeniu ofiary za grzechy ${ }^{24}$. Septuaginta zaś obydwa tłumaczy jako $\alpha \mu \alpha \rho \tau i \alpha$. Rzeczownik hatțā’ $\underline{t} \mathrm{w}$ znaczeniu ofiary za grzechy występuje na przykład w Wj 29, 14. 36 25. Wersety te są częścią narracji o konsekracji Aarona i jego synów na kapłanów. Ofiarą za ich grzech (hațta 't $t$ ) ma być młody cielec złożony w ofierze. Aaron i jego synowie mają najpierw włożyć ręce na jego głowę przed Namiotem Spotkania (Wj 29, 10). Tam też cielec ma zostać zabity. Jego krwią ma być namaszczony ołtarz, na którym należy spalić jego tłuszcz i obie nerki. Reszta cielca ma być spalona poza obozem.

Jeszcze bardziej wyrazistym tłem dla Pawłowego rozumienia Chrystusa jako ofiary za grzechy ludzi są rozdziały 4 i 5 Księgi Kapłańskiej. Młody cielec złożony w ofierze w taki sam sposób, jak w omówionym powyżej fragmencie z Wj 29, ma być zabity jako ofiara przebłagalna za całą społeczność (Kpł 4, 21). Logika tej ofiary wydaje się być oczywista. Lud poprzez włożenie rąk na cielca zrzuca swoje grzechy na niego. Dalsze zaś złożenie cielca w ofierze i jego spalenie ma skutkować zniszczeniem zrzuconych na niego

${ }^{22}$ Por. S. KIM, The Origin of Paul's Gospel, Grand Rapids 1982, s. 276 n.

${ }^{23}$ Zob. H. A. W. Meyer, Critical and Exegetical Hand-Book to the Corinthians, English transl. with supplementary notes by T. W. Chambers, New York 1884, s. 539.

${ }^{24}$ Zob. M. J. Harris, The Second Epistle to the Corinthians..., dz. cyt., s. 452.

${ }^{25}$ Statystycznie rzecz ujmując, rzeczownik ten występuje w Biblii Hebrajskiej 155 razy w znaczeniu ,grzech, jako chybienie celu” oraz 135 razy w znaczeniu „ofiara za grzechy, ofiara przebłagalna" - por. W. L. Holladay, A Concise Hebrew and Aramaic Lexicon of the Old Testament. Based upon the Lexical Work of Ludwig Koehler and Walter Baumgartner, Leiden 2000, BibleWorks 7, 2474. 
grzechów. Wydaje się, że tą samą logikę dostrzega Paweł w wydarzeniu śmierci Jezusa i do takiego jej rozumienia nawiązuje w 2 Kor 5, 21. Apostoł może nawiązywać tutaj bardzo konkretnie do żydowskiej praktyki Dnia Przebłagania (Pojednania) Jôm Hakkippurîm opisanej w Kpł 16. W tym to jednym z najważniejszych dni żydowskiego kalendarza społeczność narodu wybranego zbierała się, aby złożyć „dwa kozły na ofiarę przebłagalną za grzechy (hatțà't $)$ i jednego barana na ofiarę całopalną $(K p ł 16,5)$. Jeden z tych kozłów był zabijany w ofierze za grzechy społeczności” (Kpł 16, 1519). Na drugiego zaś kozła Aaron w geście włożenia rąk na jego głowę miał zrzucić wszystkie grzechy Izraelitów ( hatțtà t $\underline{\text { ) }}$. Po czym kozioł był wypędzany na pustynię, by tam ponieść śmierć (Kpł 16, 20-22) ${ }^{26}$.

Starotestamentowym tłem Pawłowego rozumienia wyrażenia $\dot{\alpha} \mu \alpha \rho \tau i \alpha \nu$

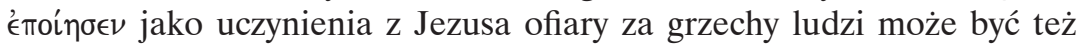
Czwarta Pieśń Sługi Pańskiego z Iz 53. Tradycje nowotestamentowe interpretowały śmierć krzyżową Jezusa w świetle tego tekstu. Iz 53, 8 stwierdza: „Zgładzono Go z krainy żyjących; za grzechy mego ludu został zabity na śmierć". W 53, 10 zaś prorok interpretuje śmierć cierpiącego sługi jako ofiarę za grzechy. Ma on dźwigać ich nieprawości, ofiarować się za nich na śmierć i być policzonym pomiędzy przestępców $(53,12)$. W oryginale hebrajskim w Iz 53, 10 ofiara życia Sługi Cierpiącego za grzechy jest określona terminem 'āšām, który w swoim podstawowym znaczeniu oznacza „winę, ukaranie”. Spośród 103 wystąpień tego rzeczownika w Biblii Hebrajskiej w około 35 przypadkach przyjmuje on znaczenie ofiary za grzechy (24 razy w Kpł, ale również w Lb 5, 7-8; 6, 12; 18, 9; 1 Sm 6, 3-4; 8, 17; 2 Krl 12, 16, w księgach prorockich zaś prócz Iz 53, 10 u Ez 40, 39; 42, 13; 44, 29; 46, $20)^{27}$. W LXX termin ten jest konsekwentnie thumaczony jako $\dot{\alpha} \mu \alpha \rho \tau i \alpha$.

Jako argument za Pawłowym rozumieniem drugiego wystąienia $\dot{\alpha} \mu \alpha \rho \tau i \alpha$ w 2 Kor 5, $21 \mathrm{w}$ sensie ofiary za grzechy podaje się dwa inne teksty Apostoła Narodów. Pierwszy z nich to Rz 8, 3, gdzie czytamy, że Bóg posłał swojego Syna $\pi \epsilon \rho \grave{\alpha} \mu \alpha \rho \tau i \alpha \varsigma$, co można tłumaczyć: ,jako ofiarę za grzechy". Argumentacja ta opiera się na tym, że Septuaginta, kiedy tłuma-

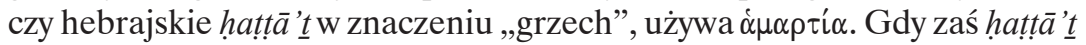

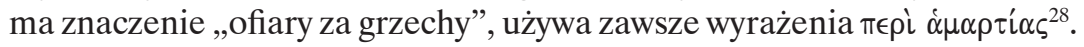
Drugi tekst to Ga 3,13, w którym wprawdzie Chrystus nie jest określony

${ }^{26}$ Motyw kozła ofiarnego jako ,typu” Chrystusa oraz wykorzystanie tej typologii w tradycji Kościoła omawiają S. Lyonnet, L. Sabourin, Sin, Redemption and Sacrifice..., dz. cyt., s. 269-289.

${ }^{27}$ Zob. Theological Wordbook of the Old Testament, t. 1-2, ed. R. L. Harris [i in.], Chicago 1980, BibleWorks 7, 180abc. 186.

${ }^{28}$ Por. M. J. Harris, The Second Epistle to the Corinthians..., dz. cyt., s. 452, przypis 
jako $\alpha \mu \alpha \rho \tau$ tí, jednakże treść tego wersetu koresponduje z 2 Kor 5, 21. Paweł przekonuje w Ga 3,13, że dla wykupienia ludzi z przekleństwa Prawa sam Chrystus stał się przekleństwem przez to, że „zawisnął na drzewie” (cytat z Pwt 21, 23). Mówiąc o przekleństwie Prawa Paweł ma z pewnością na myśli ludzkie grzechy, a zawiśniecie na drzewie jest bezpośrednim odwołaniem się do śmierci krzyżowej Jezusa ${ }^{29}$.

Przeprowadzone do tej pory analizy zmierzały do wyeksponowania

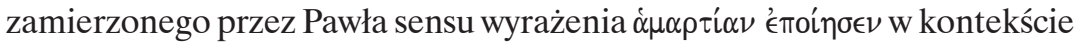

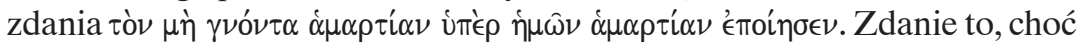
dobrze osadzone w kontekście perykopy 2 Kor 5, 11-21, ma charakter stwierdzenia ogólnego. Do natury takich wypowiedzi należy to, że z założenia są pomyślane jako otwarte na wielość interpretacji. Dotyczy to zarówno zagadnienia bezgrzeszności Chrystusa, jak i tego, kiedy i w jaki sposób Bóg uczynił Go grzechem. Najwięcej uwagi poświęciliśmy tutaj ukazaniu ewen-

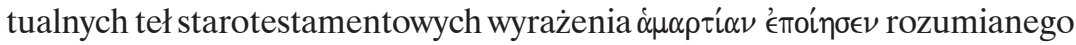
jako „ofiara za grzechy” i odnieśliśmy to wyrażenie do wydarzenia śmierci krzyżowej Jezusa dla zgładzenia grzechów świata. Nie uważamy jednak, by była to interpretacja ekskluzywna. Do przyjęcia są wszystkie interpre-

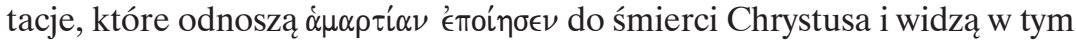
wydarzeniu moment, w którym stał się On dla nas grzechem. Wyrażenie to możemy tutaj interpretować w sposób komplementarny - wykluczamy jedynie drugą możliwość (Chrystus jako grzesznik).

\section{Skutki uczynienia Chrystusa grzechem}

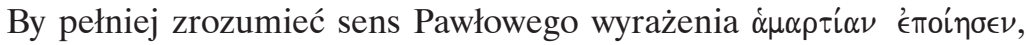
należy przeanalizować drugą część struktury koncentrycznej wchodzącej w skład wersetu 21 . Wszystkie przeanalizowane dotychczas elementy mają swoje strukturalne odpowiedniki w wersecie 21b:

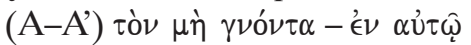

(B-B') $\dot{\alpha} \mu \alpha \rho \tau i \alpha \nu-\delta \iota \kappa \alpha \iota \sigma o v ́ \nu \eta \theta \in o \hat{~}$

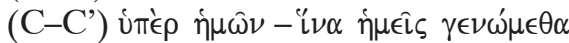

Spójnik łączności podrzędnej ǐ $\nu \alpha$ rozpoczynający zdanie w wersecie 21b wprowadza relację hipotaktyczną i wskazuje, że dalsza treść tego wersetu będzie rozwinięciem i wyjaśnieniem myśli podjętej w wersecie 21a. Wypowiedzenie zawarte w wersecie 21 b należy interpretować jako zdanie podrzędne celowe, w którym Paweł wyjaśnia, w jakim celu Bóg uczynił Chrystusa grzechem. Częściowo ta odpowiedź została już dana w wersecie 21a: ữé $\grave{\eta} \mu \omega ̂$. Paweł chce jednakże uświadomić Koryntianom, jaki jest

${ }^{29}$ Zob. F. J. MATERA, Galatians, Collegeville 1992, s. 120. 
konkretny skutek zbawczego wydarzenia dokonanego „przez” i „w” Chrystusie. Po spójniku ¿ $\nu \alpha$ Apostoł stawia zaimek osobowy i $\mu \epsilon \hat{\iota} \varsigma$, który zgodnie z zasadami gramatyki greckiej ma tutaj wartość emfatyczną. Niewątpliwie, skoro werset 21 jest częścią listu pisanego do konkretnej wspólnoty, Paweł ma tutaj na myśli przede wszystkim siebie i Koryntian, którym chce uświadomić zbawcze skutki śmierci Jezusa. Jednakże kontekst tej perykopy jasno pokazuje, że Apostoł nadaje śmierci Chrystusa wymiar uniwersalistyczny (werset 14: „skoro Jeden umarł za wszystkich, to wszyscy pomarli”; werset 15: „a właśnie za wszystkich umarł Chrystus”; werset 19: „albowiem w Chrystusie Bóg jednał ze sobą świat”). Nieuzasadnione wydaje się być również odnoszenie tej wypowiedzi Pawła do wiecznego przeznaczenia każdego człowieka (poprzez analogię do takich tekstów Pawłowych, jak 1 Kor 15, 52-54; 1 Tm 6, 15-16; 2 Tm 4, 8) 30. Wszystko, co Paweł tutaj mówi, odnosi się do aktualnego stanu wierzących w Chrystusa.

Koniunktiwus w aoryście $\gamma \in \nu \omega ́ \mu \epsilon \theta \alpha$ ma wartość pozaczasową - może odnosić się zarówno do przeszłości, teraźniejszości, jak i do przyszłości. Aspekt tego czasownika wskazuje na czynność jednorazową. Chodzi więc zapewne o to, że śmierć Jezusa była jednorazowym wydarzeniem, poprzez które Bóg pojednał świat ze sobą (w. 19) i które stawia grzesznika w zupełnie nowej sytuacji egzystencjalnej wobec Boga. M. J. Harris uważa, że kluczem do prawidłowej interpretacji całego zdania rozpoczynającego się od ${ }^{\prime} \nu \alpha$ jest czasownik $\gamma^{\prime} \nu \mu_{\alpha} \iota^{31}$. Zakres znaczeniowy tego czasownika w Nowym Testamencie jest bardzo szeroki. J. H. Thayer klasyfikuje jego nowotestamentowe wystąpienia w pięciu punktach ${ }^{32}$ : (1) zaistnieć, stać się (u Pawła np. Rz 1, 3; Ga 4, 4); (2) przydarzyć się, stać się równym komuś lub czemuś (np. Rz 3, 4; 7, 7; Ga 2, 17; 1 Kor 6, 15); (3) pojawić się (np. Mk 1, 4; J 1, 6; 1 P 2, 1); (4) zostać uczynionym, ukończonym (np. J 10, 22; Ga 3, 17; 1 Kor 9, 15); (5) zostać kimś lub czymś (np. Rz 11, 6; 2 Kor 1, 18; 7, 14). Interpretacja

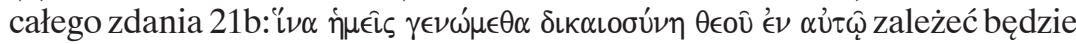

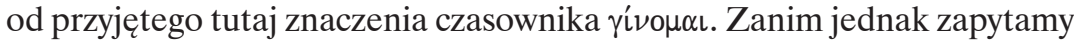
o zamierzony przez Pawła sens tego czasownika w 2 Kor 5, 21, należy wy-

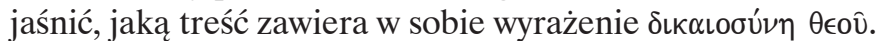

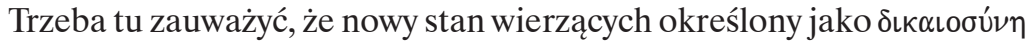

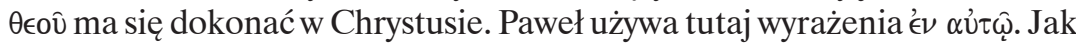

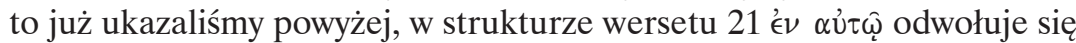

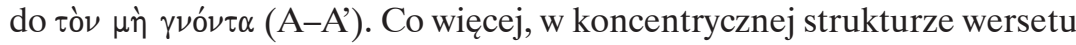
21 zachodzi związek symetryczny przeciwstawny pomiędzy rzeczownikiem

${ }^{30}$ Zob. M. J. Harris, The Second Epistle to the Corinthians..., dz. cyt., s. 454.

${ }^{31}$ Zob. tamże.

${ }^{32}$ J. H. ThaYer, A Greek-English Lexicon of the New Testament, BibleWorks 7, 1148. 


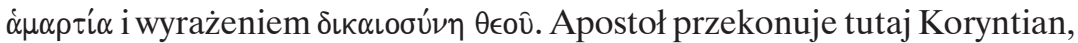
że ich nowy stan egzystencji został im wysłużony przez to, że bezgrzeszny Chrystus został uczyniony grzechem. Ich pojednanie z Bogiem i nowy spo-

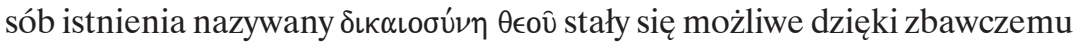
wydarzeniu, które z inicjatywy samego Boga dokonało się w Chrystusie.

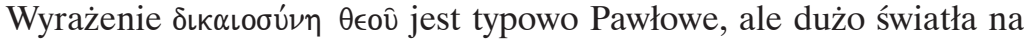
jego rozumienie przez apostoła może rzucić Mt 6, 33: „Starajcie się naprzód

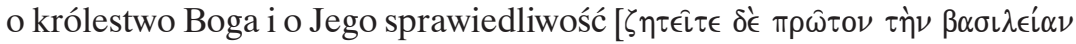

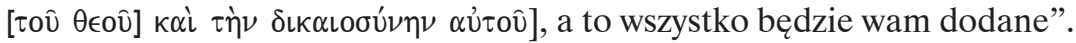
Ten fragment Kazania na Górze pokazuje, że sprawiedliwość Boża była widziana przez pierwotne chrześcijaństwo jako atrybut królestwa Bożego. Czwarte zaś błogosławieństwo (Mt 5, 6) z tego samego Kazania na Górze pokazuje, że taka sprawiedliwość powinna być przedmiotem pragnień

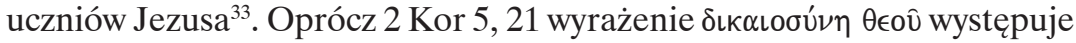

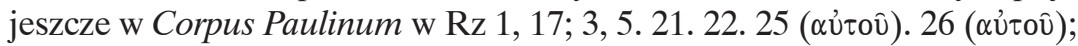
10, 3 (2 razy); Flp 3, 9. Fragment Rz 1, 17 wraz z uprzednim wersetem 16 stanowi strukturalnie streszczenie treści całego listu ${ }^{34}$. Sprawiedliwość Boża jest tutaj widziana przez Pawła jako „wychodząca od wiary i prowadząca ku wierze". Stanowi ona przedmiot objawienia głoszonej przez Pawła Ewan-

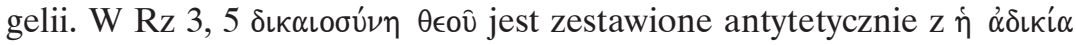
$\dot{\eta} \mu \omega \hat{v}$ („nasza nieprawość”). W dalszej części (3, 21-31) apostoł wyjaśnia, jak pojmuje Bożą sprawiedliwość: jest ona niezależna od Prawa, osiąga się ją przez wiarę w Jezusa Chrystusa (wersety 21-22). Jest dostępna dla wszystkich, którzy zgrzeszyli, i jest darmowym darem wysłużonym przez Chrystusa Jezusa, którego Bóg ustanowił „narzędziem przebłagania” (wersety 24-25). Sprawiedliwość jest przymiotem Boga i staje się udziałem każdego, kto wierzy w Jezusa (werset 26). W Rz 10, 3 Paweł wyjaśnia chrześcijanom w Rzymie, że obecny stan nieprzyjęcia Bożej sprawiedliwości przez Izraela i uporczywe trzymanie się własnej sprawiedliwości płynącej z Prawa jest wynikiem niezrozumienia. Flp 3, 9 wraz z szerszym kontekstem stanowi rekapitulację Pawłowej nauki o Bożej sprawiedliwości: „I owszem, nawet

${ }^{33}$ Inne dwa wystąpienia tego wyrażenia w Nowym Testamencie to Jk 1, 20 i 2 P 1, 1. W pierwszym z tych tekstów autor przekonuje, że gniew ludzki sprzeciwia się Bożej sprawiedliwości. W 2 P wyrażenie to występuje w adresie Listu, gdzie autor stwierdza, że wiara adresatów jest wynikiem sprawiedliwości Jezusa Chrystusa, który jest ich Panem i Zbawicielem.

${ }^{34}$ Istnieje zasadnicza zgodność wśród egzegetów, że Rz 1, 16-17 stanowi klucz do interpretacji Listu do Rzymian (a zwłaszcza jedenastu początkowych rozdziałów); por. J.-N. AletTI, Comment Dieu est-il just? Clefs pour interpréter l'épître aux Romains, Paris 1991, s. 36-38; G. RAFIŃski, Grzech ludzkości i dar usprawiedliwienia (List św. Pawła do Rzymian), [w:] Dzieje Apostolskie. Listy św. Pawła, red. J. Frankowski, S. Mędala, Warszawa 1997, s. 306-307; S. WiтKowski, Rz 1, 16-17 jako główna teza Listu do Rzymian, „Ruch Biblijny i Liturgiczny” 2 (2006), s. 97-104. 
wszystko uznaję za stratę ze względu na najwyższą wartość poznania Chrystusa Jezusa, Pana mojego. Dla Niego wyzułem się ze wszystkiego i uznaję to za śmieci, bylebym pozyskał Chrystusa i znalazł się w Nim - nie mając mojej sprawiedliwości pochodzącej z Prawa, lecz Bożą sprawiedliwość otrzymaną przez wiarę w Chrystusa, sprawiedliwość pochodzącą od Boga, opartą na wierze - przez poznanie Jego: zarówno mocy Jego zmartwychwstania, jak i udziału w Jego cierpieniach - w nadziei, że upodabniając się do Jego śmierci, dojdę jakoś do pełnego powstania z martwych” (3, 8-11). Pawłowa nauka o Bożej sprawiedliwości znajduje tu dalsze, jakże istotne doprecyzowanie, a mianowicie odniesienie do zmartwychwstania Chrystusa. Poprzez wiarę w Chrystusa apostoł ma udział w Bożej sprawiedliwości, dzięki czemu staje się uczestnikiem Jego cierpienia i doświadcza mocy Jego zmartwychwstania. W ten sposób upodabnia się do Chrystusa i nosi w sobie nadzieję własnego zmartwychwstania ${ }^{35}$.

$\mathrm{Z}$ gramatycznego punktu widzenia rzeczownik $\theta \in \mathrm{\epsilon ô}$ w wyrażeniu

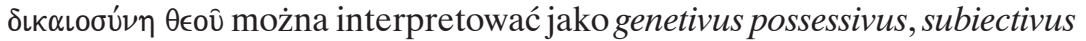
lub obiectivus. W pierwszym przypadku chodziłoby Pawłowi o wyeksponowanie prawdy, że Bóg jest posiadaczem sprawiedliwości. W drugim, że Bóg jest podmiotem udzielającym ludziom swojej sprawiedliwości - dopełniacz ten można tu sprecyzować jako genetivus auctoris. Interpretując zaś $\theta \in \mathrm{ev}$ jako genetivus obiectivus wyrażenie to należałoby tłumaczyć jako „sprawiedliwość, która dotyczy Boga - przed Bogiem”36.

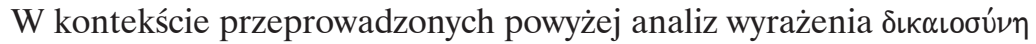
$\theta \in o v ̂$ można teraz zapytać o zamierzony przez Pawła sens czasownika $\gamma \in \nu \omega \dot{\omega} \mu \theta \alpha$. Jeżeli zinterpretujemy $\theta \in \mathrm{\epsilon}$ jako genetivus possesivus lub subiecti-

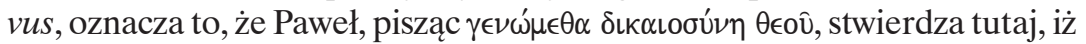
wierzący stają się posiadaczami sprawiedliwości posiadanej przez Boga albo co najmniej partycypują w sprawiedliwości, której On udziela. To uczestnictwo w Bożej sprawiedliwości oznaczałoby doświadczanie przez wierzących skutków zbawczego dzieła Chrystusa ${ }^{37}$. Przyjmując, że $\theta \in o ̂ ি$ funkcjonuje w tym wyrażeniu jako genetivus obiectivus, czasownik $\gamma \in \nu \omega \mu \mu \Theta \alpha$ wyrażałby tutaj działanie wierzących w Chrystusa polegające na życiu w sprawiedliwości, której treścią jest sam Bóg. „Bycie Bożą sprawiedliwością” oznaczałoby tutaj

${ }^{35}$ Szczegółową egzegezę tego tekstu zob. w: S. MęDALA, Świadectwo mocy Chrystusa (List do Filipian), [w:] Dzieje Apostolskie. Listy św. Pawta, red. J. Frankowski, S. Mędala, Warszawa 1997, s. 399-401.

${ }^{36}$ M. J. HARris, The Second Epistle to the Corinthians..., dz. cyt., s. 455.

${ }^{37}$ Taką interpretacją przyjmują na przykład: A. Plummer, A Critical and Exegetical Commentary on the Second Epistle of St. Paul to the Corinthians, Edinburgh 1915, s. 187; C. WolfF, True Apostolic Knowledge of Christ: Exegetical Reflections on 2 Corinthians 5.14ff, [w:] Paul and Jesus. Collected Essays, ed. A. J. M. Wedderburn, Sheffield 1989, s. 96. 
po prostu „życie dla Boga"38. Ta interpretacja 2 Kor 5, 21 znajduje mocne echo w innym tekście Pawłowym, mianowicie w Rz 6, 10-11.

Trudno tutaj ostatecznie rozsądzić, jaki jest zamierzony przez Pawła sens

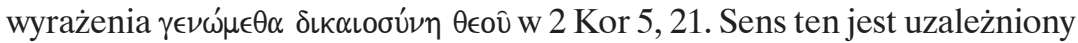

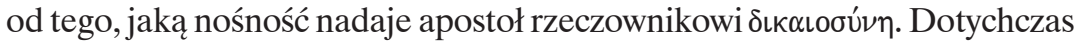
interpretowaliśmy go jako pojęcie abstrakcyjne wyrażające sprawiedliwość jako przymiot Boga. Stąd zaproponowane przez nas do tej pory interpre-

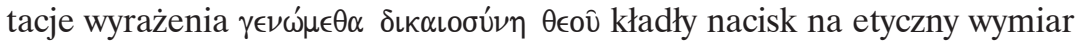
uczestnictwa wierzących w Chrystusa w Bożej sprawiedliwości. W naszej

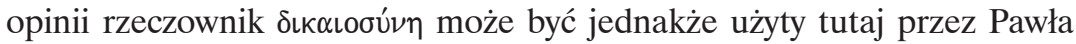

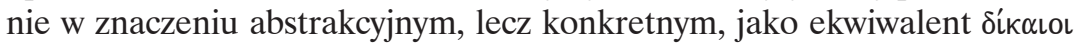
lub $\delta\left\llcorner\kappa \alpha \iota \omega \theta^{\prime} \in \tau \tau \epsilon \varsigma\right.$. Akcent nie spoczywałby więc na etycznych kwalifikacjach wierzących w Chrystusa, lecz na ontologicznej przemianie, która dokonała się w nich poprzez to, że Chrystus dla nich został uczyniony grzechem ${ }^{39}$.

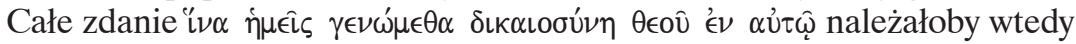
przetłumaczyć: ,abyśmy w Nim zostali usprawiedliwieni przed Bogiem” lub „abyśmy w Nim stali się sprawiedliwymi wobec Boga”. W tym kulminacyjnym zdaniu podsumowującym argumentację rozpoczętą w 5, 11 Paweł ukazuje Koryntianom, że dzięki dziełu zaplanowanemu przez Boga i zrealizowanemu w śmierci Chrystusa, otrzymują oni nowy status - stają się sprawiedliwymi wobec Boga, to znaczy zostają usprawiedliwieni ze swoich grzechów. To zaś oznacza stan polegający na przywróceniu przez śmierć Chrystusa na krzyżu właściwej relacji wierzącego z Bogiem, która została zniszczona przez grzech. W ten sposób Paweł podsumowuje swoją argumentację i wezwanie do pojednania z Bogiem rozwijane zwłaszcza w 5, 18-21.

Przeprowadzone w tym artykule analizy ukazują geniusz Pawła w formułowaniu podstawowej prawdy chrześcijańskiej wiary. W 2 Kor 5, 21 zawarte jest bowiem streszczenie istoty Ewangelii Pawłowej, której źródłem jest osobiste doświadczenie spotkania Chrystusa zmartwychwstałego w drodze do Damaszku. W nieco enigmatycznej wypowiedzi, w której ani Bóg, ani Chrystus nie są wymienieni explicite, znajdujemy wszystkie istotne elementy chrześcijańskiej Dobrej Nowiny o zbawieniu:

- inicjatorem dzieła zbawienia jest sam Bóg;

${ }^{38}$ Taką interpretację proponują np. Interpreting 2 Corinthians 5:14-21. An Exercise in Hermeneutics, ed. by J. P. LewIs, Lewiston 1984, s. 105; W. ThüsIng, Gott und Chrystus in der paulinischen Soteriologie, t. 1: Per Christum in Deum. Das Verhältnis der Christozentrik zur Theozentrik, Münster 1986, s. 108.

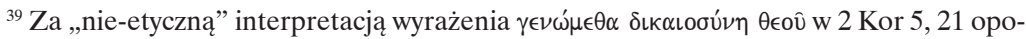
wiadają się np. G. E. LADD, A Theology of the New Testament, rev. by D. A. Hagner, Grand Rapids 1993, s. 487; M. J. Harris, The Second Epistle to the Corinthians..., dz. cyt., s. 455 (autor ten widzi tutaj raczej sens sądowniczy tego wyrażenia). 
- zbawienie to dokonuje się poprzez to, że Bóg „uczynił Chrystusa grzechem", co należy rozumieć jako wydanie Go na śmierć krzyżową;

- celem Bożej inicjatywy zrealizowanej w śmierci Chrystusa jest wyzwolenie wierzących z grzechów, by byli sprawiedliwymi wobec Boga;

- w kontekście fragmentu 2 Kor 5, 18-21 bycie sprawiedliwym wobec Boga należy rozumieć jako bycie pojednanym z Bogiem poprzez ofiarniczą śmierć Chrystusa na krzyżu.

Warszawa

JANUSZ KRECIDEO MS

\section{Summary}

Why God made Christ to be sin (2 Cor 5, 21)?

The article consists of two parts referring to Paul's argumentation in 2 Cor $5: 21$. The first one presents an extensive analysis of the enigmatic Paul's statement $\dot{\alpha} \mu \rho \tau \tau^{\prime} \alpha v$ غ̇ंoí $\sigma \varepsilon v$ in the broader context of the Apostle's disquisition. Paul's statement that 'God made Christ to be sin' may be interpreted in various ways. The most probable background for understanding the Apostle's statement seems to be the sacrifice cult of the Old Testament. God made Christ a sacrifice for the sins ( $\dot{\alpha} \mu \alpha \rho \tau i \dot{\alpha})$ of the world in the act of His martyr death on the cross. The aim of God's actions (issue discussed in the second part of the article) was to make people the

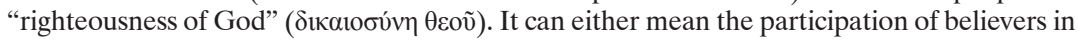
the righteousness of God or having a new identity of being righteous/justified in front of God. 